\title{
Genetic relationships and virulence factors among classical enteropathogenic Escherichia coli serogroup 0126 strains
}

\author{
WING CHEONG YAM, R. M. ROBINS-BROWNE* and MARIA LI LUNG +
}

Department of Microbiology, University of Hong Kong, Hong Kong

\begin{abstract}
Summary. Thirty-nine Escherichia coli strains of the enteropathogenic (EPEC) serogroup O126 isolated from sporadic and outbreak cases of infantile diarrhoea between 1982 and 1988 were studied. These strains consisted of four serotypes showing close genetic relationships between their virulence markers, outer-membrane protein and lipopolysaccharide profiles, and electrophoretic types by multilocus enzyme electrophoresis. None of these strains exhibited localised adherence to HEp-2 cells or the attaching-effacing properties of classical type I EPEC. Of the 39 strains, 31 were of serotype O126: H12 and enterotoxigenic; one strain was serotype O126:H10 and enteroaggregative. The remaining six strains of serotype O126:H21 and one strain of serotype O126:H8 harboured no known virulence factors for diarrhoeagenic E. coli.
\end{abstract}

\section{Introduction}

The principal evidence for enteropathogenicity in Escherichia coli has been derived from epidemiological studies of different outbreaks. Certain strains of $E$. coli have been implicated as causative agents of several clinically distinct diarrhoeal syndromes. ${ }^{1,2}$ Five recognised classes of $E$. coli - enteropathogenic (EPEC), enteroinvasive (EIEC), enterohaemorrhagic (EHEC), enteroaggregative (EAggEC) and enterotoxigenic (ETEC) - can cause diarrhoeal diseases in man. Each class has a characteristic phenotype and corresponding genotype which allows differentiation from nonpathogenic strains. Among the pathogenic attributes of EPEC is the capacity to produce distinctive microscopic lesions in the intestinal mucosa, known as attachment and effacement, and it is associated with a chromosomal locus, termed eae. ${ }^{3}$ A second genetic locus, found in most EPEC strains, is the EPEC attachment factor (EAF). This is located on a plasmid that regulates expression of eae and also codes the ability of bacteria to adhere to cultured epithelial cells in a distinctive pattern known as localised adherence. ${ }^{4}$ As in shigellosis, EIEC invade and multiply within the mucosal cells lining the large bowel, causing inflammation and ulceration. It has been shown that the invasive property of EIEC is borne on a plasmid. ${ }^{5}$ For EHEC, two types of cytotoxin have been recognised and implicated as possible causes of haemorrhagic

Received 14 May 1993; revised version accepted 2 Sept. 1993.

* Present address: Department of Microbiology, Royal Children's Hospital, Victoria 3052, Australia.

$\dagger$ Present address: Department of Biology, Hong Kong University of Science and Technology, Hong Kong. colitis. ${ }^{6}$ ETEC elaborate a heat-labile enterotoxin (LT) resembling cholera toxin (CT), a heat-stable enterotoxin (ST), or both. Genes encoding production of LT and ST occur on transmissible plasmids. ${ }^{7}$ E. coli with aggregative adherence patterns to intestinal mucosa are known as EAggEC; they are associated epidemiologically with persistent diarrhoea in infants, especially in developing countries. ${ }^{8}$

Earlier studies have indicated that $E$. coli possess a clonal population structure consisting of groups of bacteria with highly uniform properties; therefore, the bacteria within each group can be considered to have descended from a single ancestral cell, and can be referred to as clones. ${ }^{9}$ A successful taxonomic analysis of $E$. coli population structures would yield valuable insight into microbial ecology and pathogenicity. Because of the potential instability of many microbial traits, clonal analysis of pathogenic $E$. coli by new molecular techniques has proved to be more discriminating than conventional methods for epidemiological typing. ${ }^{10}$

E. coli strains of the $\mathrm{O} 126$ serogroup are implicated in human enteric disease and the serogroup is recognised as one of the classical EPEC $O$ groups. ${ }^{1,2}$ The aim of this study was to assess the overall genetic relationships and virulence along 0126 strains obtained from cases of infantile diarrhoea collected over a 6-year period by means of outer-membrane protein (OMP) and lipopolysaccharide (LPS) profiles, virulence markers, enzyme polymorphisms detected by multilocus enzyme electrophoresis and other phenotypic traits. 


\section{Materials and methods}

\section{Strains}

Thirty-nine isolates of E. coli serogroup $\mathrm{O} 126$ were collected from infants and children suffering from diarrhoea in Hong Kong and Guangzhou, People's Republic of China, between 1982 and 1988, as described previously. ${ }^{11,12}$ These included 15 strains isolated from an outbreak at a maternity hospital in Hong Kong during 1982. Selected DNA probes were investigated for their ability to hybridise with the individual test strains by colony and Southern blotting techniques as described previously. ${ }^{11,12}$ The DNA probes were derived from the following plasmids (the corresponding virulence-associated property is given in parentheses): pEWD299 (LT, heat-labile toxin); pSLM004 (ST-H, heat-stable enterotoxin of ETEC, human subtype); pRIT10036 (ST-P, heat-stable enterotoxin of ETEC, porcine subtype); pCVD419 (adhesion-associated plasmid of EHEC); pCVD432 (AggA, adhesion-associated plasmid of EAggEC); pSLM852 (DA, associated with diffused-adherence ability of $E$. coli); pJPN16 (EAF, associated with the plasmid-encoded localised-adherence phenotype of EPEC); pCVD434 (eae gene, associated with the attaching-effacing ability of $E$. coli); pJN37-19 (Shigalike toxin type I of EHEC); pNN110-18 (Shiga-like toxin type II of EHEC); and pRM17 (enteroinvasive capacity of EIEC). ${ }^{11,13-16}$

\section{DNA analysis}

Plasmid DNA was extracted by the method of Kado and Liu. ${ }^{17}$ Electrophoresis was performed in horizontal agarose gels, and after transfer to nitrocellulose by the method of Southern, hybridisation was performed with ${ }^{32} \mathrm{P}$-labelled DNA probes as described previously. ${ }^{11,12}$

\section{Serogrouping and serotyping}

Serogrouping of enteropathogenic E. coli (EPEC) strains was performed with Burroughs Wellcome $E$. coli antisera by standard procedures. ${ }^{18,19}$ EPEC was screened by slide agglutination, initially with polyvalent $\mathrm{O}$ antisera then with monovalent $\mathrm{O}$ antisera, of $E$. coli colonies. The serogrouping results were confirmed by tube agglutination of heat-inactivated $E$. coli suspensions with monovalent $O$ antisera. Serotyping with $\mathrm{H}$ antisera was performed by $\mathrm{Y}$. Takeda of the University of Tokyo and T. Tsukamoto of Osaka Prefectural Institute of Public Health, Osaka.

\section{Outer-membrane protein analysis}

OMPs were prepared by the method of Achtman $e t$ al. ${ }^{20}$ The OMPs, extracted from $100 \mathrm{ml}$ of a midexponential phase bacterial culture, were suspended in $50 \mu \mathrm{l}$ of electrophoresis sample buffer containing 0.0625 м Tris, pH 6.8, SDS $2 \%$ v/v, glycerol $10 \% \mathrm{v} / \mathrm{v}$, bromophenol blue $0.002 \% \mathrm{v} / \mathrm{v}$ and mercaptoethanol $5 \% \mathrm{v} / \mathrm{v}$. Each sample was boiled for $10 \mathrm{~min}$ before SDS gel electrophoresis. A polyacrylamide gel was prepared with a resolving gel $10 \% \mathrm{w} / \mathrm{v}$ overlaid by a stacking gel $2.5 \% \mathrm{w} / \mathrm{v}$. Resolving gel buffer was $3 \mathrm{M}$ Tris, pH 8.8 , and stacking gel buffer was $0.5 \mathrm{M}$ Tris, pH 6.8. The tank running buffer contained $0.25 \mathrm{M}$ Tris, $\mathrm{pH} 8.3,1.92 \mathrm{M}$ glycine and SDS $1 \% \mathrm{w} / \mathrm{v}$. Samples were loaded and electrophoresis was performed at a constant current of $20 \mathrm{~mA}$ (stacking gel) and $30 \mathrm{~mA}$ (resolving gel) for $4 \mathrm{~h}$. The gel was stained with Coomassie Blue $0.3 \% \mathrm{w} / \mathrm{v}$ overnight at room temperature, destained with a solution of methanol:acetic acid: water $(3: 1: 6)$. A protein mol.-wt marker (Rainbow $\left.{ }^{(m)}\right)$ was electrophoresed in parallel with the samples.

\section{Lipopolysaccharide analysis}

Whole-cell lysates were prepared according to the method of Hitchcock et al ${ }^{21}$ A polyacrylamide gel was prepared with resolving gel $12.5 \% \mathrm{w} / \mathrm{v}$ overlaid by a stacking gel $4 \% \mathrm{w} / \mathrm{v}$. For each sample, $60 \mu \mathrm{l}$ of extract was subjected to SDS-PAGE with Tris-glycine SDS $0.1 \% \mathrm{w} / \mathrm{v}$ buffer, $\mathrm{pH} 8.3$ at $35 \mathrm{~mA}$ for $3 \mathrm{~h}$ followed by silver staining. ${ }^{21}$

\section{Enzyme electrophoresis}

Cultures were grown overnight at $37^{\circ} \mathrm{C}$ in $100 \mathrm{ml}$ of nutrient broth. Cells were harvested by centrifugation at $15000 \mathrm{~g}$ for $10 \mathrm{~min}$, suspended in buffer containing $10 \mathrm{~mm}$ Tris, $1 \mathrm{~mm}$ EDTA, $0.5 \mathrm{~mm}$ NADP, $\mathrm{pH} \mathrm{6.8}$, and sonicated (20 cycles, $15 \mathrm{~s}$ on, $20 \mathrm{~s}$ off; MSE Soniprep 150 cell disrupter) with cooling in an ice bath. Unbroken cells were removed by centrifugation at $30000 \mathrm{~g}$ for $20 \mathrm{~min}$ and $10 \mu \mathrm{l}$ of the supernate was subjected to horizontal starch gel electrophoresis at $40 \mathrm{~V}$ for $4 \mathrm{~h}$; selective protein staining was performed as described previously. ${ }^{22}$ The following nine enzymes were assayed: malate dehydrogenase, 6phosphogluconate dehydrogenase, adenylate kinase, $\beta$-galactosidase, phosophoglucose isomerase, isocitrate dehydrogenase, glucose 6-phosphate dehydrogenase, mannose phosphate isomerase and leucine aminopeptidase. For each enzyme, distinctive mobility variants were designated as electromorphs and numbered in order of decreasing rate of anodal migration. Distinctive profiles of electromorphs, corresponding to unique multilocus genotypes, were designated as electrophoretic types (ETs).

\section{Haemagglutination tests}

Colonisation factor antigens I and II (CFA/I and CFA/II) were detected by the mannose resistant haemagglutination test (MRHA) with human group A, bovine, guinea-pig and chicken erythrocytes ${ }^{23,24}$ Cultures of E. coli were grown overnight at $37^{\circ} \mathrm{C}$ on CFA agar casamino acids $1 \% \mathrm{w} / \mathrm{v}$, yeast 
Table. Characteristics of E. coli serogroup 0126

\begin{tabular}{|c|c|c|c|c|c|c|c|c|c|c|}
\hline $\begin{array}{l}\text { Number of } \\
\text { isolates }\end{array}$ & H-type & Strain no. & ET & $\begin{array}{l}\text { Iso-enzyme } \\
\text { score* }\end{array}$ & $\begin{array}{c}\text { LPS } \\
\text { pattern }\end{array}$ & $\begin{array}{c}\text { OMP } \\
\text { pattern }\end{array}$ & Toxin & CFA/I & $\begin{array}{l}\text { HEP-2 cell } \\
\text { adhesion }\end{array}$ & $\begin{array}{l}\text { DNA probe } \\
\text { hybridisation }\end{array}$ \\
\hline 2 & $\mathrm{H} 12$ & A1-A2 & 1 & 113112212 & 1 & 1 & ST & + & NA & ST-H \\
\hline 3 & $\mathrm{H} 12$ & B1-B3 & 2 & 113102212 & 1 & 1 & ST & + & NA & ST-H \\
\hline 26 & H12 & $\mathrm{C} 1-\mathrm{C} 26$ & 3 & 112112212 & 1 & 1 & ST & + & NA & ST-H \\
\hline 5 & H21 & D1-D5 & 4 & 121213213 & 2 & 2 & $\ldots$ & - & NA & $\ldots$ \\
\hline 1 & $\mathrm{H} 21$ & E1 & 5 & 111211111 & 2 & 2 & $\ldots$ & - & NA & $\ldots$ \\
\hline 1 & $\mathrm{H} 8$ & $\mathrm{~F} 1$ & 1 & 113112212 & 2 & 3 & $\ldots$ & - & NA & $\ldots$ \\
\hline 1 & $\mathrm{H} 10$ & G1 & 6 & 121213213 & 3 & 4 & $\ldots$ & - & AA & AggA \\
\hline
\end{tabular}

LPS, Lipopolysaccharide; OMP, outer-membrane proteins; NA, not adherent; AA, aggregative adherence; ET, electrophoretic type; ST, heatstable enterotoxin; CFA, colonisation factor antigen; ST-H, heat-stable enterotoxin of ETEC, human subtype; AggA, adhesion-associated plasmid of EAggEC.

* Listed in order: malate dehydrogenase, 6-phosphogluconate dehydrogenase, adenylate kinase, $\beta$-galactosidase, leucine aminopeptidase, phosophoglucose isomerase, isocitrate dehydrogenase, glucose 6-phosphate dehydrogenase and mannose phosphate isomerase.

a

A B C D E F G H I J K L M N

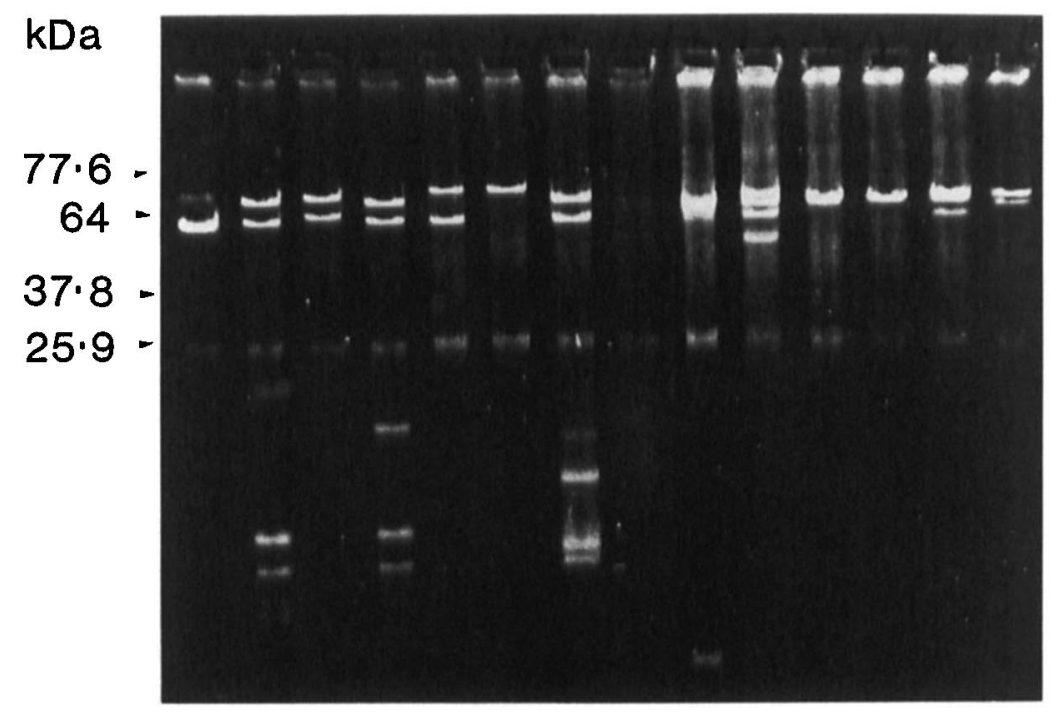

b

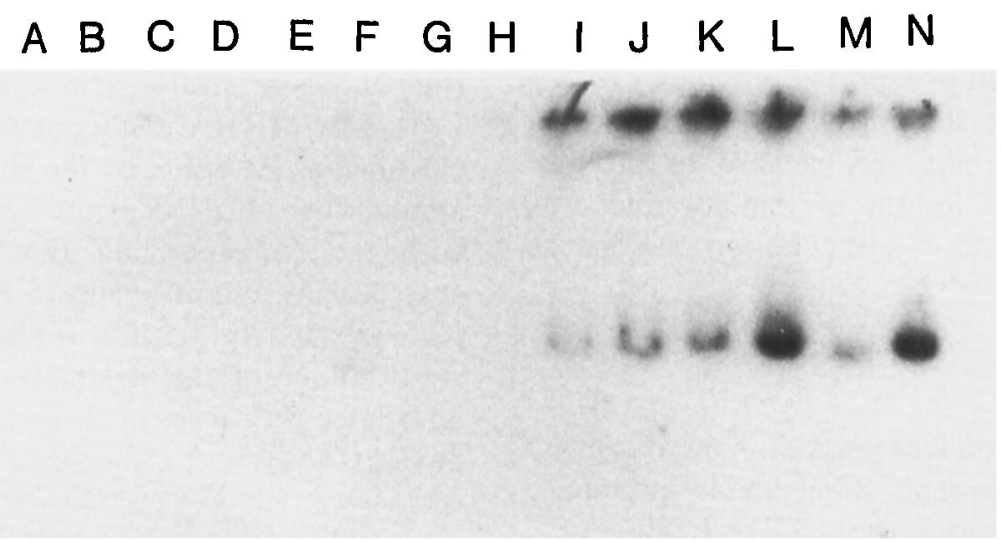

Fig. 1. Identification of ST-H plasmid in representative isolates of $E$. coli serogroup O126: a, ethidium bromide visualisation of plasmids: $\mathbf{b}$, autoradiogram of plasmids probed with ST-H. Lanes: A, O126: H8 (strain F1); B, D-G, O126:H21 (strains D1, D4, E1); C, O126:H10 (strain G1); H, E. coli K12; I-N, O126:H12 (strains A1, C5, B2, B3, C1, C20).

extract $0 \cdot 15 \% \mathrm{w} / \mathrm{v}, \quad \mathrm{MgSO}_{4} \quad 0.005 \% \mathrm{w} / \mathrm{v}, \quad \mathrm{MnCl}_{2}$ $0.0005 \% \mathrm{w} / \mathrm{v}$ in agar $2 \% \mathrm{w} / \mathrm{v}$. Erythrocytes were washed several times with phosphate-buffered saline (PBS), $\mathrm{pH} 7 \cdot 2$, and the washed cells were diluted 1 in 4 with PBS to test for haemagglutination and 1 in 4 with mannose $1 \% \mathrm{w} / \mathrm{v}$ in PBS to test for MRHA. E. coli cultures from CFA agar were mixed with a drop of the appropriate species of blood $(c .0 .02 \mathrm{ml})$ on a glass 


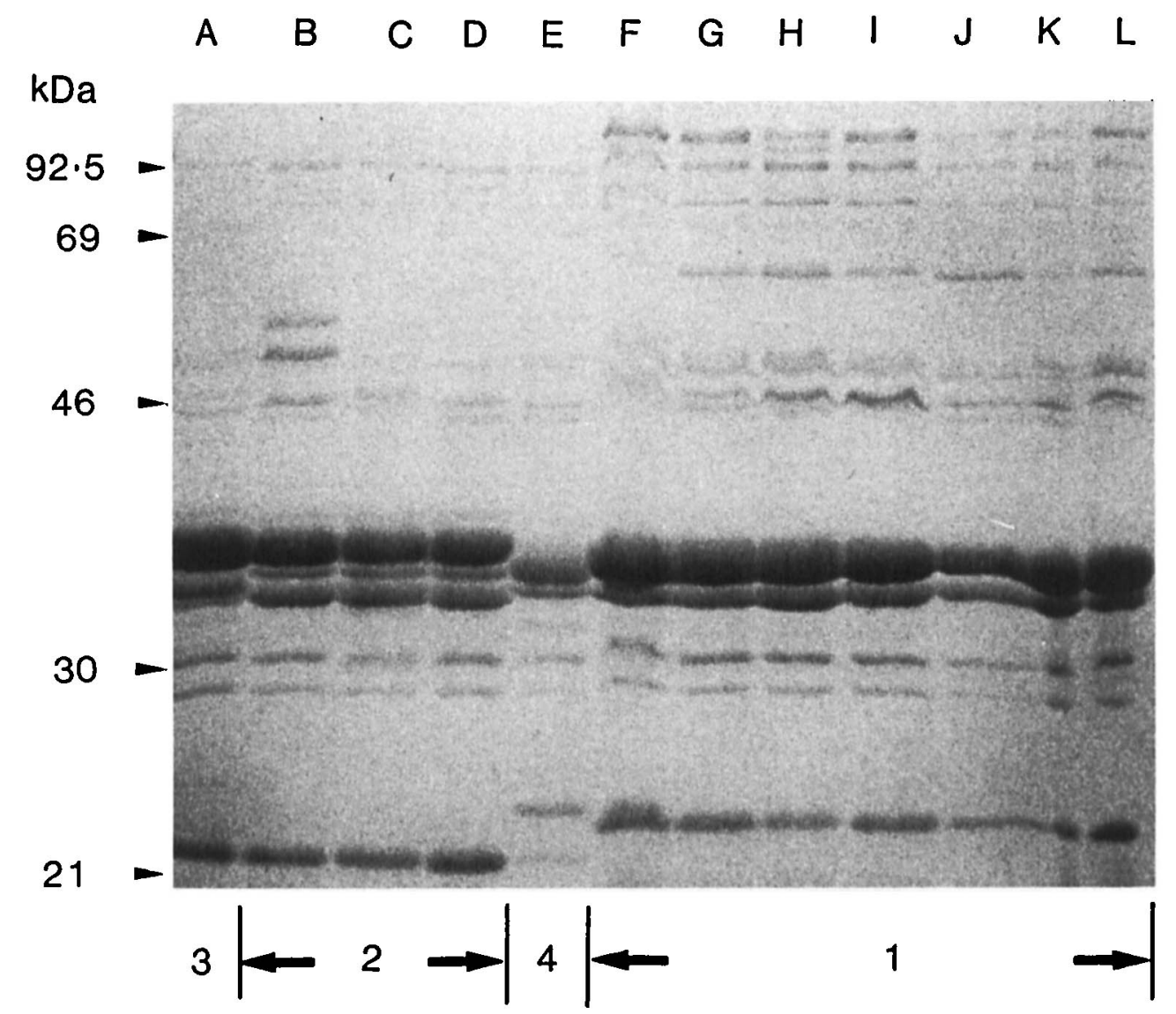

Fig. 2. SDS-PAGE of OMPs from representative isolates of $E$. coli $\mathrm{O} 126$. Clonal designations of strains according to the table are shown at the bottom. Lanes: A, O126:H8 (strain F1); B-D, O126:H21 (strains D1, D4, E1); E, O126:H10 (strain G1); F-L, O126:H12 (strains A1, $\mathrm{C} 5, \mathrm{C} 8, \mathrm{~B} 2, \mathrm{~B} 3, \mathrm{C} 1, \mathrm{C} 20$ ).

slide at room temperature. After observation for $1 \mathrm{~min}$, the slides showing less than maximum haemagglutination were placed on ice and observed for at least 2 min with intermittent mixing by rotation of the slide.

\section{Detection of bacterial adhesion to cell culture}

The pattern of bacterial adherence to HEp-2 epithelial cells was assayed as reported previously. ${ }^{16,25,26}$ The fluorescent actin staining (FAS) assay, which corresponds to the ability of bacteria to produce attachment-effacement lesions in the intestine, was performed with 3- and 6-h incubation periods as described previously. ${ }^{27,28,29}$

\section{Assay for enterotoxin}

Cytotoxin production was assayed in Vero cells by the method of Marques et al. ${ }^{3}$ Biken and infant mouse assays were used to assay LT and ST of ETEC. ${ }^{31,32}$

\section{Results}

\section{Characteristics of 0126 strains}

All the isolates in this study were obtained from infants with diarrhoea from whom no other con- ventional intestinal pathogen was isolated. ${ }^{11,12}$ The most frequency serotypes present were O126: H12 (31 isolates) and O126:H21 (six isolates) (table). Isolates of $\mathrm{H} 8$ and $\mathrm{H} 10$ were found once only during the 6-year study period. DNA hybridisation showed that only the 31 O126:H12 strains harboured the ST-H toxin gene and produced positive results with the infant mouse assay. A common plasmid of identical molecular size (64 $\mathrm{kDa}$ ) was detected in these strains (fig. 1). These strains also gave positive results for CFA/I by MRHA. Only one strain (O126:H10) was classified as EAggEC by the characteristic pattern of adherence to HEp-2 cells and by the ability to hybridise with the corresponding DNA probe. Assays for enterotoxins and adhesion to HEp-2 cells correlated with DNA hybridisation for all probes used in this study. None of the strains possessed the virulenceassociated properties of classical type I EPEC, EHEC or EIEC.

\section{Genetic relationships in the 0126 serogroup}

To determine whether $E$. coli $\mathrm{O} 126$ strains associated with infantile diarrhoea were clonally related, the associated virulence and genetic relationships of $\mathrm{O} 126$ strains, which had been isolated over a 6-year period from Hong Kong and the People's Republic of China were examined. These strains were grouped into four 


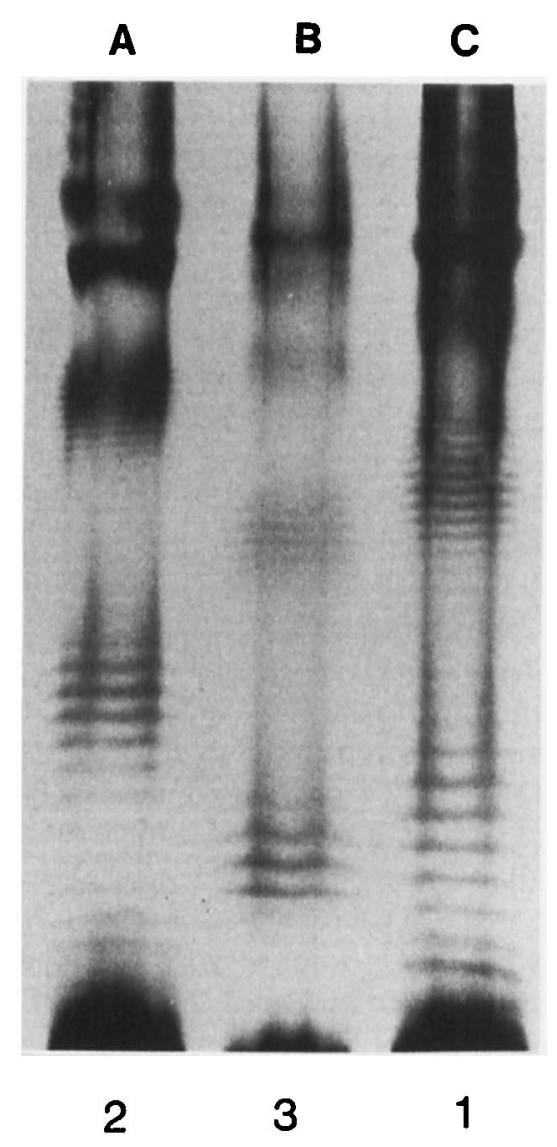

Fig. 3. SDS-PAGE of whole-cell lysates of representative isolates of $E$. coli $\mathrm{O} 126$ stained by LPS silver staining. Clonal designations of strains according to the table are shown at the bottom. Lanes: $\mathbf{A}$, O126:H21 (strain D1); B, O126:H10 (strain G1); C, O126:H12 (strain Al).

serotypes, with distinct virulence genes, ETs, OMP and LPS patterns (table). Each serotype possessed a unique OMP pattern. All isolates had major OMPs of mol. wt from 21-42 kDa (fig. 2). Four major OMP patterns were identified. On LPS analysis, O126:H12 and O126:H10 strains exhibited patterns 1 and 3, whereas $\mathrm{O} 126: \mathrm{H} 21$ and $\mathrm{O} 126: \mathrm{H} 8$ strains exhibited an identical LPS pattern, type 2 (fig. 3). In all 39 isolates, seven of the nine enzymes assayed were polymorphic. Comparisons of the multilocus genotypes of isolates revealed six ETs and the electrophoretic variation in isocitrate dehydrogenase is shown (fig. 4). Different serotypes of O126, except for the only O126: H8 strain, showed distinct ETs. The O126: H8 strain exhibited an ET identical to that of two isolates of O126: H12. All the 15 O126: H12 strains (nos. C3-C17) isolated from the same outbreak in 1982 exhibited ET 3. As regards virulence traits, ST-H and CFA/I were found associated only with $\mathrm{O} 126: \mathrm{H} 12$, and enteroaggregative activity was associated with $\mathrm{O} 126: \mathrm{H} 10$. Six strains of O126:H21 and one strain of O126:H8 had none of the known virulence factors associated with diarrhoeagenic E. coli. All E. coli O126 isolates, except O126: $\mathrm{H} 12$ which harboured a plasmid of uniform size $(64 \mathrm{kDa})$ coding for bacterial virulence, possessed diverse plasmid DNA profiles (fig. 1).

\section{Discussion}

The E. coli $\mathrm{O} 126$ strains examined were isolated at different times from various epidemiological sources. Some clonal isolates exhibited uniform properties. Correlation of virulence factors, serotypes, ETs, migration patterns of major OMPs and LPS was observed among the strains collected over a 6-year period. We propose that there is no causal association among these properties, rather that they are independent, conserved characteristics of clonal groups. It is clear from this study that there is a clonal association

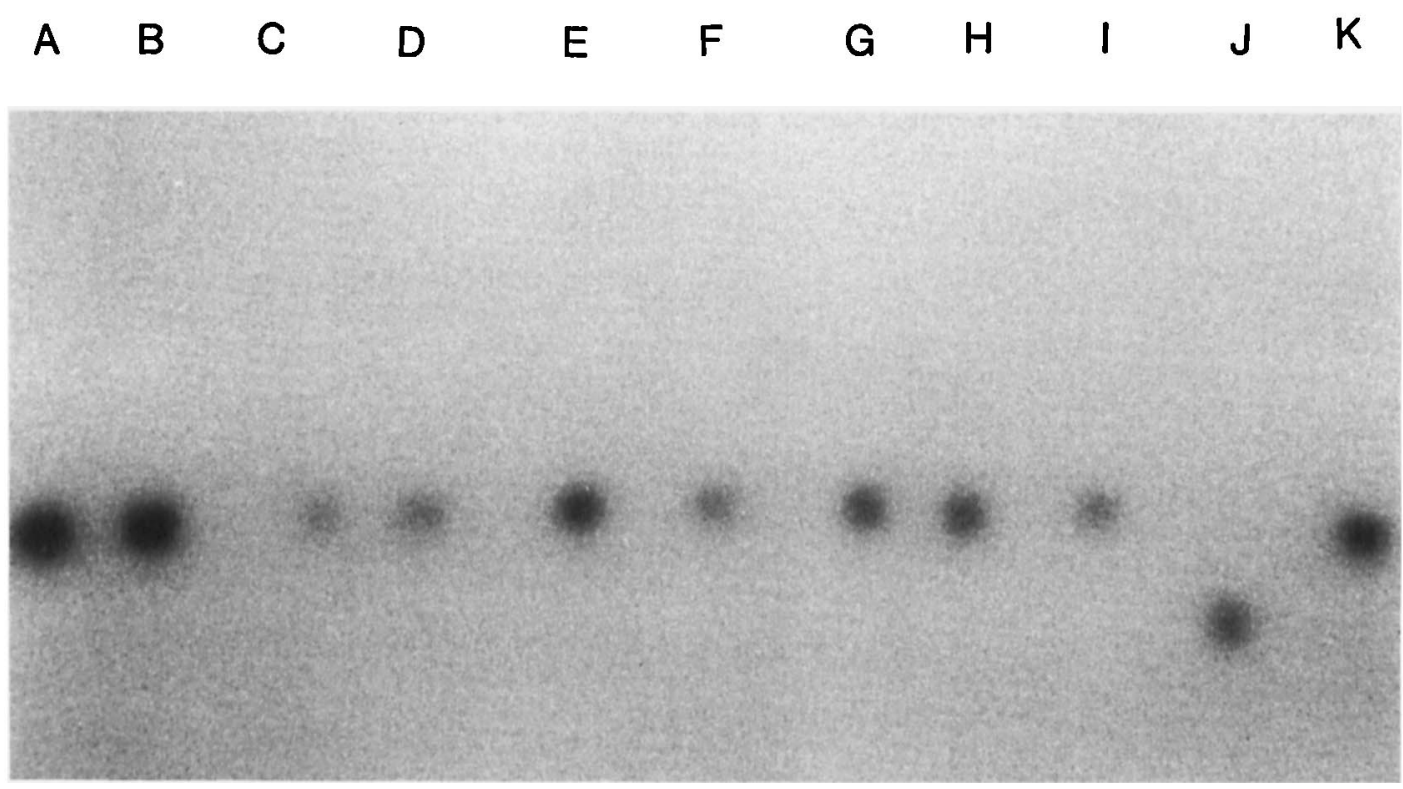

Fig. 4. Electrophoretic variation in isocitrate dehydrogenase of representative isolates of $E$. coli serogroup O126. Lanes: A-F, O126:H12 (strains A1, C5, B2, B3, C1, C20); G, O126:H8 (strain F1); H-J, O126:H21 (strains D1, D4, E1); K, O126:H10 (strain G1). 
of $E$. coli $\mathrm{O} 126$ with $\mathrm{H}$ serotypes. It has been reported with other pathogenic $E$. coli that clonality is strongly associated with $\mathrm{H}$, rather than with $\mathrm{O}$ serotypes. ${ }^{33}$

Plasmid analysis was unsuitable for recognising clonal groups, with the exception of $\mathrm{O} 126: \mathrm{H} 12$ strains, since most bacteria possess too many different plasmids. However, OMP analysis is a powerful tool which has been found to correlate well with other phenotypic characters for studying the clonal nature of EPEC. ${ }^{33,34}$ Minor differences in OMP patterns 2 and 3 suggest that $\mathrm{O} 126: \mathrm{H} 21$ and $\mathrm{O} 126: \mathrm{H} 8$ are subclones. This is supported by the identical LPS patterns of these two serotypes. The multilocus electrophoresis technique attempts to determine overall genetic relatedness among isolates by examination of a small fraction of the structural gene loci of the genome. Except for only a few strains of ET 1 present in both O126:H12 and O126:H8, each serotype consisted of strains with unique ETs.

These findings suggest that characterisation of phenotypic attributes is essential for understanding the relationships among pathogenic $E$. coli, even of the one $\mathrm{O}$ serogroup. In this collection of O126 strains, both ETEC and EAggEC were found along with two groups lacking known virulence factors. None of the strains belonged to the classic EPEC O126: $\mathrm{H} 2$ subtype, or harboured the EAF or eae virulence factors which are associated mainly with type I EPEC, as reported recently.$^{29}$ Different pathogenic mechanisms may be associated with clonal groups in E. coli $\mathrm{O} 126$ strains. In recent years, the identification of virulence factors has enabled the subdivision of classical EPEC strains into classes causing diarrhoea by different mechanisms. ${ }^{1}$ This study confirms previous findings that strains belonging to the same EPEC serogroup are a heterologous group. ${ }^{35}$ The existence of invasive and toxigenic $E$. coli strains in the same serogroup has been reported for serogroup O167. ${ }^{36}$

LPS composition may contribute to the virulence of EPEC by favouring selection of strains for the establishment, maintenance, or infectivity of the clone $^{33}$ This may account for the persistence of

\section{References}

1. Levine MM. Escherichia coli that cause diarrhea: enterotoxigenic, enteropathogenic, enteroinvasive, enterohemorrhagic, and enteroadherent. J Infect Dis 1987; 155: 377-389.

2. Robins-Brown RM. Traditional enteropathogenic Escherichia coli of infantile diarrhea. Rev Infect Dis 1987; 9: 28-53.

3. Jerse AE, Gicquelais KG, Kaper JB. Plasmid and chromosomal elements involved in the pathogenesis of attaching and effacing Escherichia coli. Infect Immun 1991; 59: 3869-3875.

4. Nataro JP, Scaletsky ICA, Kaper JB, Levine MM, Trabulsi LR. Plasmid-mediated factors conferring diffuse and localized adherence of enteropathogenic Escherichia coli. Infect Immun $1985 ; 48$ : 378-383.

5. Hale TL, Sansonetti PJ, Austin S, Formal SB. Characterization of virulence plasmids and plasmid-associated outer membrane proteins in Shigella flexneri, Shigella sonnei, and Escherichia coli. Infect Immun 1983; 40: 340-350.
O126: H12 (with type 1 LPS pattern) in this 6-year study period. A previous study showed that the enterotoxin (ENT) plasmid associated with $\mathrm{O} 126: \mathrm{H} 12$ is identical ${ }^{12}$ and the present findings on the serotype, ETs, OMP and LPS patterns of this clone further confirm the identity of the bacterial host harbouring this ENT plasmid. Maintenance of this plasmid within a cell line for at least 6 years suggests that it confers a selective advantage. In this study, the number of isolates available for the examination of the genetic relationships and pathogenic mechanisms of $E$. coli O126 was limited. However, E. coli $\mathrm{O} 126$ was not detected among 100 control subjects during the same period. ${ }^{11}$ Since toxigenic strains of 0126 were not commonly isolated in neighbouring countries, ${ }^{37}$ O126: $\mathrm{H} 12$ may represent a recent clone of ETEC from the EPEC serotype O126:H12 which has acquired the ENT plasmid in the locality. Indeed, a predominant ETEC strain that produced only ST and belonged to serotype O126:H12 was reported recently from Thailand ${ }^{38}$ The latter strain may be identical to the isolates in this study, and may reflect the spread of this clone in Southeast Asia. The finding that O126:H10, categorised as EAggEC, is noteworthy in the light of the recent report by Scotland $e t$ al. that the EPEC strains of serotype O126:H27, obtained from patients with diarrhoea in the UK, were in fact EAggEC. ${ }^{39}$

Further study of $E$. coli as a diarrhoeal agent depends on increased understanding of the pathogenesis of the disease. This study presents the results of comprehensive screening of virulence factors in diarrhoeagenic E. coli. Plasmid-borne pathogenic attributes such as enterotoxins, CFA or enteroaggregation were detected in the majority of the strains. However, none of the E. coli strains of serotypes O126:H21 and O126:H8 possessed any of the pathogenic attributes investigated.

We acknowledge Aqa Tokhi and Vicki Bennet-Wood for their excellent work on cytotoxin and FAS assays. We also thank Y. Takeda of the University of Tokyo and T. Tsukamoto of Osaka Prefectural Institute of Public Health, Osaka for serotyping analyses. We are grateful to S. Falkow, M. M. Levine, J. B. Kaper and $\mathbf{J}$. W. Newland for providing the DNA probes.

6. Scotland SM, Smith HR, Rowe B. Two distinct toxins active on Vero cells from Escherichia coli O157. Lancet 1985; 2: 885-886.

7. Sack RB. Enterotoxigenic Escherichia coli: Identification and characterization. J Infect Dis 1980; 142: 279-286.

8. Cravioto A, Tello A, Navarro A et al. Association of Escherichia coli HEp-2 adherence patterns with type and duration of diarrhoea. Lancet 1991; 337: 262-264.

9. Ochman H, Selander RK. Evidence for clonal population structure in Escherichia coli. Proc Natl Acad Sci, USA 1984; 81: 198-201.

10. Achtman M, Pluschke G. Clonal analysis of descent and virulence among selected Escherichia coli. Annu Rev Microbiol 1986; 40: 185-210.

11. Yam WC, Lung ML, Yeung CY, Tam JS, Ng MH. Escherichia coli associated with childhood diarrheas. J Clin Microbiol 1987; 25 : 2145-2149.

12. Yam WC, Lung ML, Ng MH. Clonal origin, restricted natural distribution, and conservation of virulence factors in 
isolates of enterotoxigenic Escherichia coli serogroup 0126. $J$ Clin Microbiol 1988; 26: 1477-1481.

13. Baudry B, Savarino SJ, Vial P, Kaper JB, Levine MM. A sensitive and specific DNA probe to identify enteroaggregative Escherichia coli, a recently discovered diarrheal pathogen. J Infect Dis $1990 ; 161$ : 1249-1251.

14. Boileau CR, d'Hauteville HM, Sansonetti PJ. DNA hybridization technique to detect Shigella species and enteroinvasive Escherichia coli. J Clin Microbiol 1984; 20: 959-961.

15. Jerse AE, Yu J, Tall BD, Kaper JB. A genetic locus of enteropathogenic Escherichia coli necessary for the production of attaching and effacing lesions on tissue culture cells. Proc Natl Acad Sci USA 1990; 87: 7839-7843.

16. Levine MM, Prado V, Robins-Browne RM et al. Use of DNA probes and HEp-2 adherence assay to detect diarrheagenic Escherichia coli. $J$ Infect Dis 1988; 158: 224-228.

17. Kado CI, Liu ST. Rapid procedure for detection and isolation of large and small plasmids. J Bacteriol 1981; 145: 1365-1373.

18. Edwards PR, Ewing WH. Identification of Enterobacteriaceae. 3rd edn. Minneapolis, Burgess Publishing Co. 1972: 21-47.

19. Ørskov F, Ørskov I. Serotyping of Escherichia coli. In: Bergan $\mathrm{T}$ (ed) Methods in microbiology. New York, Academic Press Inc. 1984; 14: 43-112.

20. Achtman M, Mercer A, Kusecek B et al. Six widespread bacterial clones among Escherichia coli $\mathrm{K} 1$ isolates. Infect Immun 1983; 39: 315-335.

21. Hitchcock PJ, Brown TM. Morphological heterogeneity among Salmonella lipopolysaccharide chemotypes in silver-stained polyacrylamide gels. J Bacteriol 1983; 154: 269-277.

22. Selander RK, Caugant DA, Ochman H, Musser JM, Gilmour MN, Whittam TS. Methods of multilocus enzyme electrophoresis for bacterial population genetics and systematics. Appl Environ Microbiol 1986; 51 : 873-884.

23. Evans DG, Silver RP, Evans DJ, Chare DG, Gorbach SL. Plasmid-controlled colonization factor associated with virulence in Escherichia coli enterotoxigenic for humans. Infect Immun 1975; 12: 656-667.

24. Evans DJ, Evans DG, DuPont HL. Hemagglutination patterns of enterotoxigenic and enteropathogenic Escherichia coli determined with human, bovine, chicken, and guinea-pig erythrocytes in the presence and absence of mannose. Infect Immun 1979; 23: 336-346.

25. Nataro JP, Kaper JB, Robins-Browne RM, Prado V, Vial P, Levine MM. Patterns of adherence of diarrheagenic Escherichia coli to HEp-2 cells. Pediatr Infect Dis J 1987; 6: 829-831.

26. Vial PA, Mathewson JJ, DuPont HL, Guers L, Levine MM. Comparison of two assay methods for patterns of adherence to HEp-2 cells of Escherichia coli from patients with diarrhea. J Clin Microbiol 1990; 28: 882-885.
27. Knutton S, Baldwin T, Williams PH, McNeish AS. Actin accumulation at sites of bacterial adhesion to tissue culture cells: basis of a new diagnostic test for enteropathogenic and enterohemorrhagic Escherichia coli. Infect Immun 1989; 57: 1290-1298.

28. Knutton S, Philips AD, Smith HR et al. Screening for enteropathogenic Escherichia coli in infants with diarrhea by fluorescent-actin staining test. Infect Immun 1991; 59: 365-371.

29. Robins-Browne RM, Yam WC, O'Gorman LE, Bettelheim KA. Examination of archetypal strains of enteropathogenic Escherichia coli for properties associated with bacterial virulence. J Med Microbiol 1993; 38: 222-226.

30. Marques LRM, Moore MA, Wells JG, Wachsmuth IK, O'Brien AD. Production of Shiga-like toxin by Escherichia coli. $J$ Infect Dis 1986; 154: 338-341.

31. Dean AG, Ching YC, Williams RG, Harden LB. Test for Escherichia coli enterotoxin using infant mice: application in a study of diarrhea in children in Honolulu. $J$ Infect Dis 1972; 125: 407-411.

32. Honda T, Arita M, Takeda $Y$, Miwatani T. Further evaluation of the Biken test (modified Elek test) for detection of enterotoxigenic Escherichia coli producing heat-labile enterotoxin and application of the test to sampling of heatstable enterotoxin. J Clin Microbiol 1982; 16: 60-62.

33. Ørskov F, Whittam TS, Cravioto A, Ørskov T. Clonal relationships among classic enteropathogenic Escherichia coli (EPEC) belonging to different $\mathrm{O}$ groups. $J$ Infect Dis 1990; 162: 76-81.

34. Stenderup J, Ørskov F. The clonal nature of enteropathogenic Escherichia coli strains. J Infect Dis 1983; 148: 1019-1024.

35. Beutin L, Ørskov I, Ørskov F et al. Clonal diversity and virulence factors in strains of Escherichia coli of the classic enteropathogenic serogroup O114. J Infect Dis 1990; 162: 1329-1334.

36. Gross RJ, Thomas LV, Cheasty T et al. Enterotoxigenic and enteroinvasive Escherichia coli strains belonging to a new $O$ group O167. J Clin Microbiol 1983; 17: 521-523.

37. Echeverria P, Seriwatana J, Taylor DN et al. Plasmids coding for colonization factor antigens I and II, heat-labile enterotoxin, and heat-stable enterotoxin A2 in Escherichia coli. Infect Immun 1986; 51: 626-630.

38. Echeverria P, Taylor DN, Seriwatana J, Brown JE, Lexomboon U. Examination of colonies and stool blots for detection of enteropathogens by DNA hybridization with eight DNA probes. J Clin Microbiol 1989; 27: 331-334.

39. Scotland SM, Smith HR, Said B, Willshaw GA, Cheasty T, Rowe B. Identification of enteropathogenic Escherichia coli isolated in Britain as enteroaggregative or as members of a subclass of attaching-and-effacing $E$. coli not hybridising with the EPEC adherence-factor probe. $J$ Med Microbiol 1991; 35: 278-283. 